\title{
Will Liberalizing the Services Trade between Developing and Developed Countries Solve Employment Problems in a Post- Pandemic Recovery? The Case of ACP-EU Services Trade
}

https://doi.org/10.21272/sec.5(4).74-89.2021

Manitra A. Rakotoarisoa, ORCID ID: https://orcid.org/0000-0002-5312-7350

Lead Economist, Infinite Sum Modeling LLC, USA

\begin{abstract}
The COVID-19 pandemic has exacerbated the asymmetric employment problems in the global services sector. Would a liberalization of the highly protected services trade between the rich and poorer countries help solve such problems? This paper contributes to answering that question by analyzing the impacts on welfare and employment of an hypothetical liberalization of the services trade between the Africa, Caribbean and Pacific Group of States (ACP) and their rich partners in the European Union and the United Kingdom (EU+UK). For both the ACP and EU +UK, their service sectors play important role in their economy, especially in providing jobs. The services sectors employ the majority of unskilled labor and the large majority of skilled labor. For instance, in the EU+UK, $67 \%$ of employed unskilled and $82 \%$ of employed skilled workers are in the service sectors; the respective figures for ACP countries are 54\% and 90\%. These figures indicate that any change in trade policies for the services sector will affect not just the services but also other sectors such agriculture and manufacturing in ACP and EU countries. To analyze the impacts of services trade liberalization on welfare an employment, I use a Computable General Equilibrium model that takes into account the labor productivity gaps among trading countries. Results show that although ACP services represents only about $24 \%$ of ACP's total exports to and $28 \%$ of ACP's total import from the EU+UK, halving the bilateral tariffs in services trade will generate for the ACP a welfare gain 3.4 times larger than the gain under elimination of bilateral tariffs on goods. Such liberalization of services trade will generate significant endowment effects equivalent to 410,000 new jobs per year, mostly in the services sector. The employment and welfare gains will also reach other sectors, including agriculture, as services trade costs are reduced. The liberalization of services trade will raise wages, especially for ACP's skilled labor. All these ACP's gains will increase further if its labor productivity improves. Despite a slight decline in wages for EU+UK's skilled labor, the EU+UK will gain about 7.8 billion USD in welfare. Overall, liberalization of the services trade between ACP and EU+UK will help solve their employment problems and should not be delayed.
\end{abstract}

Keywords: services sectors, employment, welfare, labor productivity, trade liberalization.

JEL Classification: D61, F13, F16, F6, J31.

Cite as: Rakotoarisoa, M. A. (2021). Will Liberalizing the Services Trade between Developing and Developed Countries Solve Employment Problems in a Post-Pandemic Recovery? The Case of ACP-EU Services Trade. SocioEconomic Challenges, 5(4), 74-89. https://doi.org/10.21272/sec.5(4).74-89.2021.

Received: 21.08.2021 Accepted: 29.11.2021 Published: 30.12 .2021

Copyright: (C) 2021 by the author. Licensee Sumy State University, Ukraine. This article is an open access article distributed under the terms and conditions of the Creative Commons Attribution (CC BY) license (https://creativecommons.org/licenses/by/4.0/).

\section{Introduction}

The economic fallouts of the COVID-19 pandemic, preceded by many years of rising protectionism (exemplified in particular by the Brexit, and the US-China trade war), have resulted in a tumultuous and 
asymmetric employment problem in the global services sector. In many developed countries, bus and truck drivers as well as providers of many other basic services have now been in short supply. Contrastingly, in lowincome and emerging economies, unemployment in almost all sectors especially in the services sector (e.g. the hospitality and tourism industries) is surging fast. These problems contributed to the disruption of the global supply chains in goods and services, jeopardizing the already fragile post-pandemic economic recovery.

Globally, the service sector directly employs $70 \%$ of the unskilled labor and about $85 \%$ of skilled labor. The services sector also produces $24 \%$ and $32 \%$, respectively, of intermediate goods used in the key sectors such as agriculture and manufacturing. In both developed and developing countries despite the significant contribution of the services sector to employment and welfare, trade in many important services subsectors such as communication, insurance, and transport remain highly protected (van Limburg, 2010; Fontagné et al., 2011).Would a liberalization of the highly protected services trade between developed and developing countries help alleviate the current plight of the services sector?

The purpose of this paper is to estimate the welfare and employment effects of a simulated liberalization of services trade between the ACP group and their rich, traditional partners in the EU+UK. Since the trade negotiation between the ACP and the EU+UK countries under the renewed Economic Partnership Agreement (EPA), the liberalization of trade in the highly protected services sector has been stalled by numerous issues stemming mainly from fears of losing tax revenues and employment (Brenton, 2010; Bendini et al., 2012). For example, negotiators feared that the significant labor productivity gap in the service sectors between the EU and the ACP could lead to employment loss, specifically the loss of employment for less- skilled jobs in the EU+UK and that of more skilled jobs in the ACP. Another cause for the delay is the concern on whether the liberalization in services trade will help or harm the liberalization in the form of the much-anticipated reciprocal tariffs elimination in the goods trade. Adequate information regarding the overall welfare and employment effects of the liberalization of services trade in conjunction with the liberalization in goods trade is, thus, needed.

This paper uses a general equilibrium, the Global Trade Analysis Project (GTAP), model (Hertel, 1997) to simulate the elimination of bilateral tariffs in goods and halving of the bilateral tariff equivalent in services for EU+UK and ACP trade. The main innovation by this paper is that the differences in labor productivity trends among the trading partners are fully taken into account. The scenarios are precisely designed to determine the distribution of the welfare and employment gains or losses, as well as changes in wage among regions and sectors. I examine also the impacts of the service trade liberalization on wage and employment in manufacturing and agriculture, as these sectors host the bulk of the poor small input owners in many low-income countries, especially in Sub-Sahara African countries within the ACP. To my knowledge, no study has attempted to perform such analysis. The findings are intended to provide policy implications for unlocking the potential of services trade between $\mathrm{ACP}$ and EU+UK in solving their employment problems, and in boosting the postpandemic economic recovery.

\section{Features of the ACP-EU Services Trade}

\subsection{Employment problems in the services sectors in ACP and EU+UK}

The ACP and EU+UK countries have made progress in negotiating the liberalization of goods (merchandises) trade but remain reluctant to fully address the liberalization of the services trade. The main reason for the delay is uncertainty regarding the effects of such trade liberalization for welfare and employment and of trade imbalances. The COVID-19 pandemic, despite the hardships it has caused, may inadvertently provide a new spark in revisiting the negotiations on services trade liberalization.

In the wake of the COVID-19 pandemic, for many countries in the ACP group, the unemployment problems for both skilled and less-skilled labor force that had long plagued their economy are getting worse. Because of the travel limitations and long spells of social and economic lockdowns, the services sectors such as the transportation, the hospitality and the tourism industries are among the hardest hit. Significant numbers of 
workers in these services sectors have lost employment and income; for these idle workers, reconverting to other equally ailing sectors such as agriculture and manufacturing is not an option.

For the EU+UK, the services sectors have suffered from the same pandemic fallouts but in contrast with the ACP case, they find themselves in short supply of workers in basic services sectors such as transportation, construction, and utility services. One of the reasons is that these services were mostly provided by foreign workers who went home during the pandemic but for various reasons (e.g. Brexit, sanitary barriers), never returned. A haunting image is the UK Government's enlisting of the Army to ensure fuel transportation to retailers in order to alleviate the fuel supply disruption caused by driver shortage. As both the ACP and EU+UK hope to solve these somewhat asymmetric employment problems, exploring how the liberalization of services trade could affect welfare and employment and yield mutual benefits is just timely.

\subsection{Importance of the services sectors in ACP and EU+UK trade}

Globally, services contribute up to $24 \%$ and $32 \%$ respectively of the value of intermediate goods in agriculture and manufacturing. For both the ACP and EU +UK, their service sectors play an even more important role in their economy, especially in providing jobs; services sectors employ the majority of unskilled labor and the large majority of skilled labor. For instance, in the EU+UK, $67 \%$ of employed unskilled and $82 \%$ of employed skilled workers are in the service sectors. The respective figures for ACP countries are 54\% and 90\%. These figures indicate that any change in trade policies for the services sector will affect not just the services but also other sectors such agriculture and manufacturing in ACP and EU countries. But so far, quantitative information of such impacts remains elusive.

Services trade, though overshadowed by goods trade in the Economic Partnership Agreements, is an important trade component of the trade negotiations between the ACP and the EU+UK. Data (Narayanan and Walmsley, 2008; GTAP Database, various years) show that services export represents on average $15 \%$ of total trade value of ACP countries (reaching 35\% for the Caribbean and Pacific group within the ACP) and about and 22\% of total trade of EU+UK countries. More important, services represent non-negligible parts of the ACP trade with the EU+UK: ACP services export to the EU+UK represents about $24 \%$ of the ACP total exports to the EU+UK, and $28 \%$ of ACP imports from the EU+UK are services.

Although services trade is an important component of trade between ACP and EU+UK trade, the balance remains in favor of the EU+UK. Services trade data (Figure 1) show that the ACP as a whole is a net importer vis-à-vis the EU+UK in all except in the communication, transportation and utility subsectors. In other large subsectors such as finance and business services and construction services, the ACP is a net importer, which could be attributed to many reasons including the different sizes of the economies, differences in labor skills and productivity, and differences in capital endowment between the two trading blocs. 


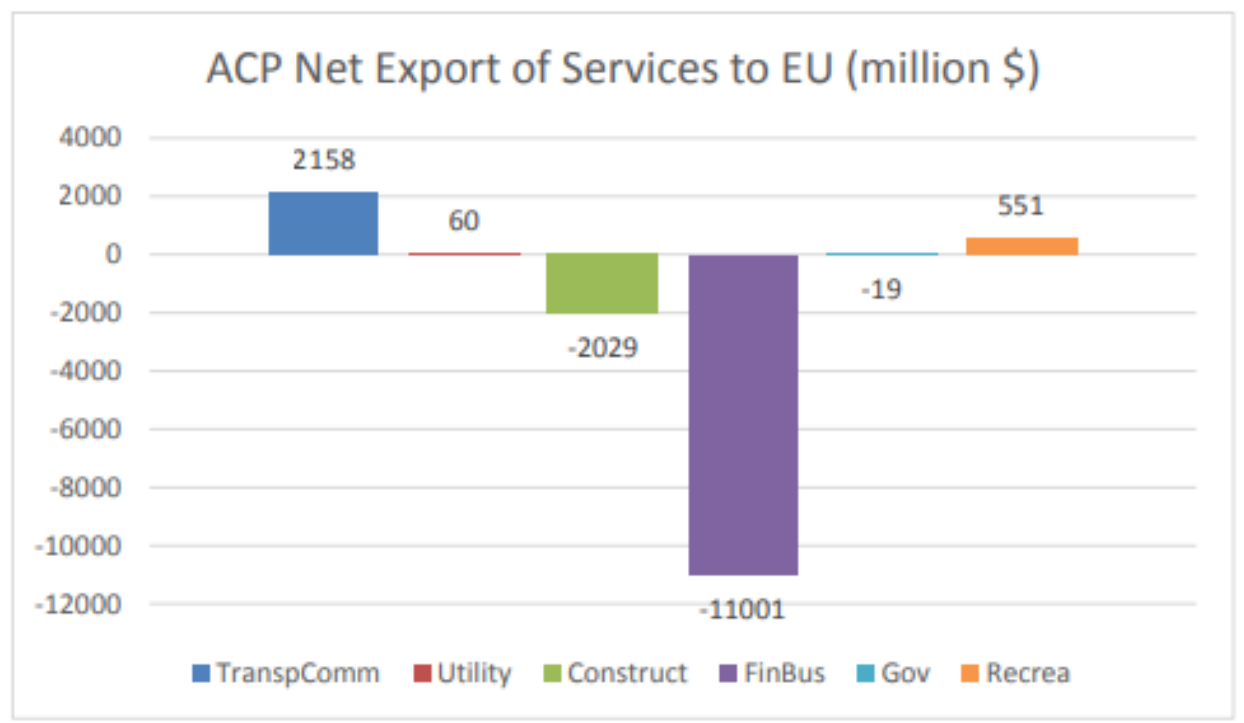

Figure 1. ACP net export of services to the EU

Source: GTAP 8.

\subsection{High barriers and trade costs in the service sectors}

Uncertainties over total welfare and employment effects of the liberalization in services trade are also due in part to high barriers and trade costs on both sides. To date, data on the level of barriers remain patchy. The difficulties reside in measuring the trade distortion, because undeclared non-tariff barriers seem to prevail. There are also many hidden costs of services trade (linked to merchandise trade) that create complications in the estimation.

However, the few available data on the distortions in services trade point to a high trade cost in services trade in both the EU+UK and the ACP. For instance, Fontagné et al. (2011) provide a measure of the tariff equivalent showing that trade costs are particularly high for both developing and developed countries (Table 1). It seems obvious that any sensible reduction of these high barriers and trade costs will have significant impacts on ACP services trade values and welfare.

Table 1. Tariff equivalent for selected services sectors in selected countries

\begin{tabular}{|c|c|c|c|c|c|c|c|c|c|c|}
\hline & Communication & Construction & $\begin{array}{c}\text { Financial } \\
\text { Services }\end{array}$ & Insurance & $\begin{array}{c}\text { Business } \\
\text { services }\end{array}$ & $\begin{array}{c}\text { Public admin } \\
\text { Defence } \\
\text { Education } \\
\text { Health }\end{array}$ & Trade & $\begin{array}{c}\text { Transport } \\
\text { nec }\end{array}$ & $\begin{array}{c}\text { Water } \\
\text { transport }\end{array}$ & Average \\
\hline France & 37.6 & 36.4 & 50.7 & 61.7 & 35.6 & 39.8 & 42 & 20.3 & 40.9 & 40.6 \\
\hline Great Britain & 23 & 84.9 & 19.6 & 36 & 30.9 & 16 & 34.6 & 6.1 & 38 & 32.1 \\
\hline Germany & 22.3 & 15 & 30.4 & 39.3 & 16.6 & 23.7 & 18.8 & 10.8 & 38.1 & 23.9 \\
\hline Mauritius & 62.9 & 101.9 & 60.2 & 27.2 & 19.3 & 36 & 47.8 & 16.8 & 31.1 & 44.8 \\
\hline South Africa & 73.4 & 144 & 116.2 & 36.2 & 73.2 & 51.3 & 70.1 & 39 & 79.2 & 75.8 \\
\hline
\end{tabular}

Source: Fontagné et al. (2011).

\subsection{Significant gaps in labor productivity}

An important feature of the services trade between the ACP and the EU+UK countries is the significant gaps in labor productivity between the two trading blocs. As in the agriculture or manufacturing sectors, van Dijk (2013) shows, as reported in Table 2, that there is a huge gap in labor productivity in the service sectors (such as finances and business services), especially between ACP countries and the rest of the world including the EU+UK. This productivity gap exacerbates the uncertainty regarding employment impacts of services trade 
liberalization. If services trade is liberalized, the EU+UK fears of losing services jobs to the ACP, especially jobs that require less skilled workers. Conversely, the ACP fears of losing some of its already strained skilled labor supply to the EU+UK. This is why addressing the likely impacts of the liberalization in the service sectors on ACP and EU+UK employment is important.

Table 2. Labor productivity growth by major sectors: Projection 2006-2050 (\% per year)

\begin{tabular}{|l|c|c|c|c|c|c|c|c|c|c|c|}
\hline & \multicolumn{9}{|c|}{ Main Selected Regions } \\
\hline & $\begin{array}{c}\text { Industrialized } \\
\text { countries }\end{array}$ & China & India & $\begin{array}{c}\text { Asian } \\
\text { Tiger }\end{array}$ & $\begin{array}{c}\text { Asia } \\
\text { Developing }\end{array}$ & Brazil & $\begin{array}{c}\text { Rest of } \\
\text { Latin America }\end{array}$ & $\begin{array}{c}\text { Sub- } \\
\text { Saharan } \\
\text { Africa }\end{array}$ & $\begin{array}{c}\text { Rest of } \\
\text { The } \\
\text { World }\end{array}$ \\
\hline \multicolumn{7}{|c|}{} & \multicolumn{7}{|c|}{ Sector: } \\
\hline Agriculture & 3.43 & 4.11 & 1.48 & 4.23 & 2.59 & 4.87 & 2.39 & 2.14 & 2.59 \\
\hline Construction & -1.05 & 3.96 & -0.18 & 0.38 & -1.49 & 0.29 & -0.64 & 2.69 & 2.59 \\
\hline $\begin{array}{l}\text { Finance and insurance real } \\
\text { estate }\end{array}$ & 1.32 & 1.72 & -4.86 & 0.28 & -1.14 & -1.52 & -1.55 & -0.57 & n.a \\
\hline Manufacturing & 1.74 & 7.00 & 1.59 & 4.55 & 1.82 & -0.98 & 0.46 & -6.30 & 1.82 \\
\hline $\begin{array}{l}\text { Transport storage and } \\
\text { communication }\end{array}$ & 2.37 & 5.40 & 4.22 & 3.05 & 0.86 & -2.17 & 1.17 & 2.04 & 1.82 \\
\hline Wholesale and retail trade & 1.41 & 3.11 & 2.96 & 2.29 & -1.81 & -2.04 & -2.34 & 4.89 & 0.95 \\
\hline Other Services & -0.63 & 4.58 & 3.42 & 0.89 & 0.95 & 0.27 & 0.05 & -4.00 & n.a \\
\hline Overall & 1.17 & 5.46 & 3.17 & 2.38 & 1.53 & -0.14 & 0.42 & 0.37 & 1.53 \\
\hline
\end{tabular}

Source: van Dijk, 2013.

\section{Model}

\subsection{Model description}

I use a General Equilibrium (GE) analysis based on the static GTAP model (Hertel, 1997) to estimate the impacts of liberalization of the services trade between ACP and EU+UK countries on welfare and employment. The GTAP model is a multi-sector, multi-country model that provides an accounting exercise of how shocks such as changes in tariff and input productivity growth rates in service sectors affect prices and incomes, and hence welfare and employment. Changes in welfare as results of any policy shocks are captured as an equivalent variation; employment effects are captured by the endowment effect component of the total welfare effect. The advantage of using the GTAP model is its access to detailed trade data on all sectors, including the various service sectors.

The GTAP model is one of the most widely used GE models and features market-clearing conditions for outputs (across domestic and exports), imports (by users as firms, households and government), domestic consumption (by users as assigned for imports), and endowment output (by usage in various sectors). Zero profits are assumed in the standard form of this model, implying perfect competition. This condition is employed to infer the endogenous output change in every sector.

Because an important emphasis of this study is on the labor productivity gaps in ACP-EU trade, I summarize here how shifts in productivity and technical progress are captured in the model. The production function $Y$ in the GTAP model is in a Leontief form for which output is produced from primary inputs (mainly land, labor, and capital) nested in and source (i.e. domestic and foreign source) differentiated intermediate inputs. The primary inputs (land, labor and capital) are imperfect substitutes in a nested CES function $Q_{v}$. The technological shifts in domestic production in the GTAP model are through a Hicks-neutral (for overall productivity) shift at the Leontieff level, and input productivity parameter shift at the second stage.

In summary, the production function is

$Y=A_{0} \cdot \min \left\{A_{i 1} \cdot Q_{i 1}, \ldots A_{i n} \cdot Q_{i n} ; Q_{v}\right\}$

where, 
$Q_{v}=\left[\sum_{e}\left(A_{e} \cdot Q_{e}\right)^{\rho}\right]^{-\frac{1}{\rho}}$

and $Y$ is output, $A_{0}$ is Hicks-neutral change parameter, $A_{i j}$ is output-per unit input coefficients, and $Q_{i j}$ is quantity of intermediate input for country $i$ from source $j \neq i$. $Q_{v}$ is the domestic second-stage CES production function using primary inputs $e ; A_{e}$ is share parameter of input $e=\{$ land, unskilled labor, skilled labor, and capital $\}$; and $-1<\rho<\infty$ is the elasticity-of- substitution parameter. The neutral shift in overall productivity is due to a shift in the parameter $A_{0}$, whereas the shifts in the productivity in the intermediate and primary inputs are due to parameters $A_{i j}$ and $A_{e}$ respectively. For this study, the technical and productivity shifts of interest are particularly on $A_{0}$ and $A_{e}$, especially for e = labor. As (1) and (2) show, these technical and productivity shifts affect production directly, which affects price and the comparative advantage of an open economy. In an open economy, technical progress and increases in productivity lead to welfare gain, due to increased competitiveness of production and export.

An increase in labor productivity, for instance, leads to an increase in the marginal value products of other inputs (especially capital). This leads to an increase in technical efficiency, which enhances welfare gain. Moreover, there can also be a gain in allocative efficiency when sectors that use labor intensively expand and attract productive labor from other sectors. This allocative efficiency effect is noticeable under full employment of resources, especially with expected rises in factor payments. When there are unemployed resources (and factor returns are more or less fixed), the increases in labor productivity and production increase the demand and hiring of resources and, as a result, the country's or region's welfare increases. The welfare effect of such an increase of the use of formerly unemployed resource is captured by the endowment effects. Additionally, the model captures the terms of trade and investment-savings adjustment effects. In this study, such welfare change is the result of trade policy shocks for the EU-ACP services trade, taking into account differences in laborproductivity trajectories (as shown earlier in Table 1) among all trading partners.

My approach is first to introduce the productivity gaps in the model using estimates of labor productivity growth rates from Van Dijk (2013) and then to embed the average tariff equivalent of protection in service sectors based on estimates by Fontagné et al. (2011). I examine various policy scenarios based on tariff and labor productivity growth rates by taking into account the progress made in the negotiation on the goods markets and including a hypothetical shock of halving the tariffs in services between EU+UK and ACP countries.

\subsection{Aggregation and Scenarios}

The GTAP model in this paper is composed of 15 regions, 10 sectors (including 6 service sectors) and 5 main factor inputs. These aggregations are as follows ${ }^{1}$ :

Regional aggregation: West Africa; Central Africa; Eastern and Southern Africa; East Africa; Caribbean and Pacific group; MENA (Middle East and North Africa); EU+UK; North America; Central and Southern America; Asia Developing (Thailand, Malaysia, Indonesia, and Vietnam); Asia Industrialized, a.k.a Japan and the Asian Tigers (Japan, South Korea, Singapore, Hong-Kong, and Taiwan); Oceania (New Zealand and Australia; BRIC (Brazil, Russia, India and China); and Rest of the World. ${ }^{2}$

Sectoral aggregation: Raw Food and Agriculture; Extraction; Textile and Apparel Manufacturing; Transport and Communication Services; Construction and Dwelling Services; Finance, Business Insurance and Trade Services; Utility (Electricity, Water, and Gas manufacture distribution) services; Government (Public Administration, Health, Education, Defense) services; and Recreation and other services.

Factor aggregation: Skilled labor; Unskilled labor; Capital; Land; and Natural resources

\footnotetext{
${ }^{1}$ See Annex 1 and Annex 2 for more details.

${ }^{2}$ The ACP countries are aggregated in the EPA groups.
} 
The model closure is mainly based on the assumptions that there are unemployment in both skilled and unskilled labor in ACP countries and unemployment in skilled labor in the EU.

The simulations are based on the following three main scenarios (see Table 3 also):

Base Case Scenario (S0): In this scenario, labor productivity differences among regional aggregation and the average tariff equivalents are introduced in the service sectors.

Scenario 1 (S1): All shocks in the baseline scenario S0 (including the introduction of labor productivity differences) are maintained, but removals of reciprocal tariffs on the goods markets between the EU and the 6 ACP groups are added;

Scenario 2 (S2): The same as Scenario 1, except that all bilateral tariffs on services are halved (reduced by $50 \%$ ). This tariff reduction is ad hoc but can be changed under many sensitivity analyses. Sensitivity analyses also include altering the rates of productivity growth.

Table 3. The scenarios

\begin{tabular}{|c|c|c|c|}
\hline & $\begin{array}{c}\text { Base Case (S0): } \\
\text { (with labor productivity } \\
\text { shocks) }\end{array}$ & $\begin{array}{c}\text { Scenario 1 (S1): } \\
\text { Liberalization in ACP-EU } \\
\text { goods trade only }\end{array}$ & $\begin{array}{c}\text { Scenario 2 (S2): } \\
\text { Liberalization in ACP-EU } \\
\text { goods and services trade }\end{array}$ \\
\hline Main Closures: & $\begin{array}{l}\text { - Unemployment of unskilled } \\
\text { labor except in emerging and } \\
\text { developed economies } \\
\text { - Fixed trade balance except } \\
\text { in emerging and developed } \\
\text { economies } \\
\end{array}$ & $\begin{array}{l}\text { - Unemployment of unskilled } \\
\text { labor except in emerging and } \\
\text { developed economies } \\
\text { - Fixed trade balance except } \\
\text { in emerging and developed } \\
\text { economies }\end{array}$ & $\begin{array}{l}\text { - Unemployment of unskilled } \\
\text { labor except in emerging and } \\
\text { developed economies } \\
\text { - Fixed trade balance except } \\
\text { in emerging and developed } \\
\text { economies }\end{array}$ \\
\hline \multicolumn{4}{|l|}{ Shocks } \\
\hline $\begin{array}{l}\bullet \quad \text { Labor } \\
\text { productivity growth* }\end{array}$ & Projection estimates & Projection estimates & Projection estimates \\
\hline $\begin{array}{l}\text { - Tariffs on goods } \\
\text { EU - ACP }\end{array}$ & No change & Zero tariff (reciprocal) & Zero tariff (reciprocal) \\
\hline $\begin{array}{l}\cdot{ }_{\text {EU- ACP }}^{\text {Tariffs on services }} \\
\end{array}$ & Ad valorem (Fontagné et al.) & Ad valorem (Fontagné et al.) & $50 \%$ reduction (reciprocal \\
\hline
\end{tabular}

Notes: * Labor productivity growth projection estimates according to Van Dijk, M., (2013).

The GTAP model employs GTAP database 8 (Narayanan and Walmsley, 2008) and GTAP database 9 that include tariffs and other trade data on 134 countries and regions and 57 commodities (sectors). These data permit the model aggregation described earlier.

\section{Results}

\subsection{Welfare Effects}

\subsubsection{With no trade liberalization on goods or services}

Simulations using the GTAP model were conducted to analyze the effects of the services trade liberalization using the base case S0 and the scenarios S1 and S2. The welfare decomposition results are reported in Table 4.

Table 4. Decomposition of the welfare changes (millions of USD)

(4a) Base case: Welfare changes by including labor productivity gaps without any changes in trade policies (millions of USD)

\begin{tabular}{|l|c|c|c|c|c|c|}
\hline & $\begin{array}{c}\text { Allocative } \\
\text { efficiency } \\
\text { effect }\end{array}$ & $\begin{array}{c}\text { Endowment } \\
\text { effect }\end{array}$ & $\begin{array}{c}\text { Technical } \\
\text { Efficiency } \\
\text { effect }\end{array}$ & $\begin{array}{c}\text { Terms of } \\
\text { trade effect }\end{array}$ & $\begin{array}{c}\text { Investment-Saving } \\
\text { effect }\end{array}$ & Total \\
\hline $\begin{array}{l}\text { 1 Eastern and Southern } \\
\text { Africa }\end{array}$ & -391.7 & -825.4 & -147.1 & 24.6 & -10.3 & -1349.9 \\
\hline 2 East Africa & -143.2 & -327.0 & 150.7 & -354.7 & -103.7 & -778.0 \\
\hline 3 West Africa & -140.8 & -416.8 & 999.1 & 1168.1 & 8.2 & 1617.8 \\
\hline
\end{tabular}


Table 4 (cont.). Decomposition of the welfare changes (millions of USD)

(4a) Base case: Welfare changes by including labor productivity gaps without any changes in trade policies (millions of USD)

\begin{tabular}{|l|c|c|c|c|c|c|}
\hline \multicolumn{1}{|c|}{$\begin{array}{c}\text { Allocative efficiency } \\
\text { effect }\end{array}$} & $\begin{array}{c}\text { Endowment } \\
\text { effect }\end{array}$ & $\begin{array}{c}\text { Technical } \\
\text { Efficiency } \\
\text { effect }\end{array}$ & Terms of trade effect & \multicolumn{3}{|c|}{$\begin{array}{c}\text { Investment-Saving } \\
\text { effect }\end{array}$} \\
\hline 4 Central Africa & 83.0 & -84.3 & 26.6 & 1225.8 & -682.4 & 568.7 \\
\hline 5 SADC & -885.8 & -1552.1 & -1137.5 & -378.5 & -4.6 & -3958.4 \\
\hline 6 Caribbean and Pacific & -1291.9 & -1878.8 & 731.5 & -2096.3 & -668.8 & -5204.3 \\
\hline 7 MENA & 1943.4 & 2174.6 & 9889.7 & 8855.9 & 212.9 & 23076.5 \\
\hline 8 North America & 11948.9 & 0.0 & 149675.3 & -250.9 & 436.4 & 161809.6 \\
\hline $\begin{array}{l}\text { 9 Central and Southern } \\
\text { America }\end{array}$ & 108.1 & -639.1 & 804.7 & 1540.9 & -30.8 & 1783.6 \\
\hline 10 EU+UK & 51601.2 & 27582.5 & 125016.4 & -3374.2 & 439.2 & 201265.0 \\
\hline 11 BRIC & 22034.4 & 56584.2 & 121764.6 & -8126.7 & 1624.8 & 193881.3 \\
\hline 12 Asia Developing & 287.4 & 376.6 & 2519.8 & 1209.9 & -173.3 & 4220.3 \\
\hline $\begin{array}{l}\text { 13 Japan and } \\
\text { the Asian Tigers }\end{array}$ & 7349.9 & 0.0 & 61510.0 & -2985.7 & -1100.2 & 64774.0 \\
\hline $\begin{array}{l}14 \text { Australia and } \\
\text { New Zealand }\end{array}$ & 1358.9 & 0.0 & 7924.4 & 990.7 & 44.0 & 10317.9 \\
\hline 15 Rest of The World & 8398.3 & 10549.4 & 24924.1 & 2551.2 & 8.5 & 46431.4 \\
\hline Total & 102260.0 & 91543.7 & 504652.2 & 0.0 & -0.1 & 698455.7 \\
\hline
\end{tabular}

Source: Author.

(4b) Scenario 1: Welfare changes from tariff elimination in goods trade w.r.t baseline (millions of USD)

\begin{tabular}{|c|c|c|c|c|c|c|}
\hline & $\begin{array}{c}\text { Allocative } \\
\text { efficiency } \\
\text { effect }\end{array}$ & $\begin{array}{c}\text { Endowment } \\
\text { effect }\end{array}$ & $\begin{array}{c}\text { Technical } \\
\text { Efficiency } \\
\text { effect }\end{array}$ & $\begin{array}{l}\text { Terms of } \\
\text { trade effect }\end{array}$ & $\begin{array}{c}\text { Investment-Saving } \\
\text { effect }\end{array}$ & Total \\
\hline $\begin{array}{l}1 \text { Eastern and Southern } \\
\text { Africa }\end{array}$ & 404.58 & 372.63 & 0 & 19.16 & 0.55 & 796.92 \\
\hline 2 East Africa & 30.86 & 70.51 & 0 & -83.92 & -42.45 & -25.02 \\
\hline 3 West Africa & 165.85 & 177.01 & 0 & -471.39 & -22.45 & -150.97 \\
\hline 4 Central Africa & 298.03 & 112.76 & 0 & -223.04 & 502.74 & 690.5 \\
\hline 5 SADC & 17.04 & 250.5 & 0 & -366.78 & -13.33 & -112.57 \\
\hline $\begin{array}{l}6 \text { Caribbean and } \\
\text { Pacific }\end{array}$ & 223.19 & 332.3 & 0 & 94.44 & -20.12 & 629.81 \\
\hline 7 MENA & -54.57 & -53.08 & 0 & -401.39 & 18.09 & -490.94 \\
\hline 8 North America & -80.39 & 0 & 0 & -249.86 & -375.89 & -706.15 \\
\hline $\begin{array}{l}9 \text { Central and Southern } \\
\text { America }\end{array}$ & -24.43 & -49.64 & 0 & -117.46 & -0.66 & -192.18 \\
\hline 10 EU+UK & 2836.92 & 1297.44 & 0 & 3304.21 & -44.7 & 7393.87 \\
\hline 11 BRIC & -146.93 & -316.1 & 0 & -714.55 & -4.08 & -1181.65 \\
\hline 12 Asia Developing & -16.59 & -18.44 & 0 & -166.01 & 17.94 & -183.11 \\
\hline $\begin{array}{l}13 \text { Japan and } \\
\text { the Asian Tigers } \\
\end{array}$ & -60.83 & 0 & 0 & -215.9 & 24.15 & -252.57 \\
\hline $\begin{array}{l}14 \text { Australia and } \\
\text { New Zealand }\end{array}$ & -13.31 & 0 & 0 & -104.01 & -14.69 & -131.99 \\
\hline 15 Rest of the World & 35.37 & -22.7 & 0 & -303.5 & -25.09 & -315.93 \\
\hline Total & 3614.81 & 2153.2 & 0 & 0 & 0 & 5768.02 \\
\hline
\end{tabular}

Source: Author. 
(4c) Scenario 2: Welfare changes from tariff elimination in goods trade and halving of services tariff w.r.t baseline (millions of USD)

\begin{tabular}{|c|c|c|c|c|c|c|}
\hline & $\begin{array}{c}\text { Allocative } \\
\text { efficiency } \\
\text { effect }\end{array}$ & $\begin{array}{c}\text { Endowment } \\
\text { effect }\end{array}$ & $\begin{array}{c}\text { Technical } \\
\text { efficiency } \\
\text { effect }\end{array}$ & $\begin{array}{l}\text { Terms of } \\
\text { trade effect }\end{array}$ & $\begin{array}{c}\text { Investment-Saving } \\
\text { effect }\end{array}$ & Total \\
\hline 1 Eastern and Southern Africa & 518.11 & 676.78 & 0 & 117.8 & 22.09 & 1334.78 \\
\hline 2 East Africa & 105.2 & 230.7 & 0 & 96.64 & 16.78 & 449.31 \\
\hline 3 West Africa & 378.4 & 634.21 & 0 & -434.13 & -23.69 & 554.79 \\
\hline 4 Central Africa & 320.69 & 184.41 & 0 & -283.32 & 748.2 & 969.98 \\
\hline $5 \mathrm{SADC}$ & 262.88 & 663.42 & 0 & 9.47 & -8.99 & 926.78 \\
\hline 6 Caribbean and Pacific & 976.18 & 1368.89 & 0 & 1176.13 & 290.87 & 3812.07 \\
\hline 7 MENA & -79.06 & -108.9 & 0 & -367.51 & 1.22 & -554.24 \\
\hline 8 North America & -174.05 & 0 & 0 & -705.5 & -639.86 & -1519.43 \\
\hline $\begin{array}{l}9 \text { Central and Southern } \\
\text { America }\end{array}$ & -28.64 & -70.68 & 0 & -142.95 & -13.61 & -255.89 \\
\hline $10 \mathrm{EU}+\mathrm{UK}$ & 3329.28 & 1833.05 & 0 & 2793.26 & -187.7 & 7767.88 \\
\hline 11 BRIC & -143.59 & -430.41 & 0 & -844.59 & -137.94 & -1556.52 \\
\hline 12 Asia Developing & -14.79 & -60.68 & 0 & -186.97 & 12.6 & -249.85 \\
\hline 13 Japan and the Asian Tigers & -18.08 & 0 & 0 & -621.86 & 10.14 & -629.8 \\
\hline $\begin{array}{l}14 \text { Australia and } \\
\text { New Zealand }\end{array}$ & -20.09 & 0 & 0 & -132.42 & -28.79 & -181.29 \\
\hline 15 Rest of the World & -51.98 & -200.9 & 0 & -474.03 & -61.29 & -788.21 \\
\hline Total & 5360.47 & 4719.89 & 0 & 0 & 0 & 10080.37 \\
\hline
\end{tabular}

Source: Author.

(4d) Net welfare gain from halving bilateral tariff equivalent on services between the ACP and the EU (millions of USD)

\begin{tabular}{|c|c|c|c|c|c|c|}
\hline & $\begin{array}{c}\text { Allocative } \\
\text { efficiency } \\
\text { effect }\end{array}$ & $\begin{array}{l}\text { Endowment } \\
\text { effect }\end{array}$ & $\begin{array}{c}\text { Technical } \\
\text { efficiency } \\
\text { effect }\end{array}$ & $\begin{array}{l}\text { Terms of } \\
\text { trade effect }\end{array}$ & $\begin{array}{c}\text { Investment-Saving } \\
\text { effect }\end{array}$ & Total \\
\hline $\begin{array}{l}1 \text { Eastern and Southern } \\
\text { Africa }\end{array}$ & 113.53 & 304.15 & 0 & 98.64 & 21.54 & 537.86 \\
\hline 2 East Africa & 74.34 & 160.19 & 0 & 180.56 & 59.23 & 474.33 \\
\hline 3 West Africa & 212.55 & 457.2 & 0 & 37.26 & -1.24 & 705.76 \\
\hline 4 Central Africa & 22.66 & 71.65 & 0 & -60.28 & 245.46 & 279.48 \\
\hline 5 SADC & 245.84 & 412.92 & 0 & 376.25 & 4.34 & 1039.35 \\
\hline 6 Caribbean and Pacific & 752.99 & 1036.59 & 0 & 1081.69 & 310.99 & 3182.26 \\
\hline 7 MENA & -24.49 & -55.82 & 0 & 33.88 & -16.87 & -63.3 \\
\hline 8 North America & -93.66 & 0 & 0 & -455.64 & -263.97 & -813.28 \\
\hline $\begin{array}{l}9 \text { Central and Southern } \\
\text { America } \\
\end{array}$ & -4.21 & -21.04 & 0 & -25.49 & -12.95 & -63.71 \\
\hline $10 \mathrm{EU}+\mathrm{UK}$ & 492.36 & 535.61 & 0 & -510.95 & -143 & 374.01 \\
\hline 11 BRIC & 3.34 & -114.31 & 0 & -130.04 & -113.86 & -374.87 \\
\hline 12 Asia Developing & 1.8 & -42.24 & 0 & -20.96 & -5.34 & -66.74 \\
\hline 13 Japan and the Asian Tigers & 42.75 & 0 & 0 & -405.96 & -14.01 & -377.23 \\
\hline 14 Australia and New Zealand & -6.78 & 0 & 0 & -28.41 & -14.1 & -49.3 \\
\hline 15 Rest of the World & -87.35 & -178.2 & 0 & -170.53 & -36.2 & -472.28 \\
\hline Total & 1745.66 & 2566.69 & 0 & 0 & 0 & 4312.35 \\
\hline
\end{tabular}

Source: Author.

Taking into account the differences in labor productivity growth rates among the 15 regions in the model, simulation results in panel (4a) shows that at the current average protection in the service sectors with no 
liberalization in goods market, the six ACP groups as a trading bloc lose about USD 10 billion per year. Contrastingly, the EU+UK gains by about USD 201 billion, 70\% of which comes from allocative and technical efficiencies and only about $10 \%$ from an increased employment income.

The base case scenario here is a reminder that current ACP trade in goods and services with the EU+UK puts the ACP at loss. The ACP loss is due in part to its less productive labor holding down its competitiveness in the international market. It is important to note, however, that the welfare impacts among ACP groups are unevenly distributed and mixed. The ACP loss is borne mainly by SADC and Caribbean and Pacific groups due specifically to decreased employment income in the services and manufacturing sectors. While four ACP groups lose, two other groups, namely Central Africa and West Africa, post some welfare gains of about USD 0.57 and 1.3 billion per year. These gains, especially for West Africa, come from the terms-of-trade effects, apparently due to relatively lower distortion than in other ACP groups vis-à-vis the EU and a higher trade volume and proximity to the EU market.

\subsubsection{With trade liberalization in goods (merchandises) trade only}

Based on the simulation results (panel $4 \mathrm{~b}$ ) from scenario S1, engaging in EPA on merchandises (abolition of bilateral tariffs between EU+UK and ACP groups) but still keeping current protection on services trade intact will increase the ACP's total welfare by about USD 1.8 billion compared to the base case. The distribution of such relatively slight gain is mixed: the Caribbean and Pacific and the Eastern and Southern Africa (mainly COMESA) groups are much better off than the rest of the ACP groups. The relatively slight welfare increase and its mixed distribution are consistent with the foot-dragging of some African countries in the negotiation on merchandises trade under the EPA. The EU+UK on the other hand will gain in total welfare (including increases in employment income from its skilled labor) about 8 billion USD from the EPA compared with the base case.

\subsubsection{With liberalization of services trade}

Comparisons of the results of the simulation (panel 4d) under scenarios S1 and S2 show that halving bilateral tariff in services (in addition to the liberalization of trade in goods) between the ACP and the EU+UK will increase ACP groups' welfare by an additional USD 6.2 billion (i.e., about USD 8 billion gain with respect to the base case scenario, as panel $4 \mathrm{c}$ shows). The gain is non-negligible relative to the small size of some of the ACP economies. More important, such a result indicates that with just a halving of the protection in service sectors, ACP groups' welfare gain is 3.4 times larger than their gain under full elimination of bilateral tariffs with the EU on goods markets. The results also show that the gain in employment income is more than $50 \%$ of the welfare gain, pointing to a significant employment effect of the liberalization of the services trade. These results place higher importance on the liberalization of the services trade for welfare improvement and especially job creation for the ACP groups.

\subsection{Trade Effects of the liberalization in services trade}

Panel $4 \mathrm{~d}$ of Table 4, the $5^{\text {th }}$ column shows that all ACP groups except Central Africa benefit from improvement of the terms of trade when service sectors trade is liberalized. The total welfare gain due to terms-of-trade effects for the whole ACP is about 1.7 billion USD; this gain is mainly due to increased volume of exports of the ACP services, especially to Transport and Communication service sector and Finance and Business service sector (see Panel 5a in Table 5). 
Table 5. Trade Impacts of halving the bilateral tariff equivalent on ACP-EU services trade

\section{(5a). Changes in ACP export to the EU+UK (volume percentage points)}

\begin{tabular}{|l|c|c|c|c|}
\hline & Construction & Finance \& Business & Transport and Communication & Recreation \\
\hline Region source & \multicolumn{3}{|c|}{} \\
\hline Eastern and Southern Africa & 35.15 & 72.32 & 72.25 & -3.61 \\
\hline East Africa & 31.09 & 68.49 & 68.36 & -6.92 \\
\hline West Africa & 37.03 & 75.58 & 74.56 & -0.74 \\
\hline Central Africa & 39.43 & 78.14 & 76.39 & 2.93 \\
\hline SADC & 35.4 & 73.09 & 72.48 & -2.13 \\
\hline Caribbean and Pacific & 29.54 & 67.25 & 67.28 & -8.62 \\
\hline
\end{tabular}

Source: Author

(5b). Changes in EU services exports to $\mathrm{ACP}$ (percentage points)

\begin{tabular}{|l|c|c|c|c|}
\hline Destination & Construction & Finance \& Business & Transport \& Communication & Recreation \\
\hline $\begin{array}{l}\text { Eastern and } \\
\text { Southern Africa }\end{array}$ & 31.01 & 30.74 & 29.39 & 0.9 \\
\hline East Africa & 32.95 & 31.18 & 31.26 & 2.72 \\
\hline West Africa & 28.94 & 26.86 & 28.25 & 0.35 \\
\hline Central Africa & 30.99 & 25.11 & 29.17 & -1.87 \\
\hline SADC & 31.85 & 29.47 & 30.07 & 1.04 \\
\hline $\begin{array}{l}\text { Caribbean and } \\
\text { Pacific }\end{array}$ & 30.19 & 32.74 & 34.38 & 2.86 \\
\hline
\end{tabular}

Source: Author.

The figures in Table 5 are the differences between the percentage changes in export volume in Scenario 2 and Scenario 1, i.e., the net changes in percentage points due to the service trade liberalization in comparison with the base case. For ACP exports to the EU+UK, although the Recreation (tourism, hotels, etc.) services sector shrinks slightly, the other sectors do well, especially Finance and Business services (67-78\%) and Transportation and Communication services (68-75\%). Similarly, EU+UK services exports to the ACP rise by about $30-34 \%$, except in the Recreation sector where export growth is low. The low response of the Recreation services to liberalization may be linked to its facing lower trade costs than other sectors.

\subsection{Employment Effects}

A simple way to account for the employment effects of the liberalization of services trade is to assume that the endowment effects of about 2.44 billion USD of the ACP groups from Table 4 Panel $4 \mathrm{~d}$ are all due to the increases in employment. In other words, with an arbitrary 500 USD wage per month, the 2.44 billion dollars endowment effect of services trade liberalization will hire about 407 thousands unskilled ACP workers who are currently unemployed. Such a figure shows the importance of services trade liberalization for ACP countries.

It is customary to suggest that the welfare gain from trade liberalization or other policy shocks can be represented by or measured equivalently to the return to factors, especially labor, i.e., employment income. Under this suggestion, Table 6 presents the changes in the value of endowment purchased by firms at agents' prices in order to indicate the income effects of the halving of the tariff in services trade between the EU+UK and ACP countries. Over all ACP groups, the values of the gain in employment in unskilled and skilled labor are about 5.2 and 2.7 billion dollars, respectively (Table 6, Panel 6a). The results also show that excepting Central Africa, all five African groups do well, but the Caribbean and Pacific group carries more than half of those employment income gains. The main reasons for this imbalance are that the Caribbean and Pacific group has a much larger services trade (35\% of their total trade), and that this group has a large Transportation and Communication sectors that will benefit from the reduction of the high tariffs in the trade of transportation services. 
Table 6. Equivalent employment Income of the net welfare gain due to halving of the bilateral Tariffs on services trade ACP-EU

(6a) Equivalent employment income gain by regions (millions of USD)

\begin{tabular}{|l|c|c|c|c|c|c|c|c|}
\hline & $\begin{array}{c}\text { Eastern and } \\
\text { Southern Africa }\end{array}$ & East Africa & West Africa & Central Africa & SADC & $\begin{array}{c}\text { Caribbean } \\
\text { and Pacific }\end{array}$ & ACP (Total) & EU+UK \\
\hline Unskilled labor & 542.0 & 483.3 & 488.2 & -71.4 & 900.7 & 2863.0 & 5205.8 & 82.9 \\
\hline Skilled labor & 226.0 & 221.1 & 183.6 & -90.4 & 545.6 & 1571.1 & 2657.1 & -50.7 \\
\hline
\end{tabular}

Source: Author.

(6b) Equivalent employment income gain by sector (millions of USD)

\begin{tabular}{|l|c|c|c|c|}
\hline & \multicolumn{2}{|c|}{ ACP } & \multicolumn{2}{c|}{ EU +UK } \\
\hline Sector & Unskilled & Skilled & Unskilled & Skilled \\
\hline 1 Agri-Food & 116.9 & 27.7 & 95.6 & 11.3 \\
\hline 2 Extraction & -40.8 & 4.6 & 6.1 & -0.1 \\
\hline 3 Textile \& Wearing App & -50.8 & -10.4 & -2.1 & 1.0 \\
\hline 4 Manufacturing & -74.6 & -38.5 & 302.6 & 177.8 \\
\hline $\begin{array}{l}\text { 5 Transport and } \\
\text { Communication Serv. }\end{array}$ & 1219.4 & 352.0 & -271.3 & -130.4 \\
\hline 6 Utility Serv. & 41.6 & 16.1 & 2.8 & 8.5 \\
\hline 7 Construction Serv. & 785.9 & 124.0 & 233.3 & 86.3 \\
\hline $\begin{array}{l}\text { 8 Finance and Business } \\
\text { Serv. }\end{array}$ & 2035.4 & 718.4 & 187.6 & 284.6 \\
\hline 9 Government Serv. & 1053.6 & 1397.7 & -480.4 & -511.4 \\
\hline 10 Recreation Serv. & 119.1 & 65.4 & 8.6 & 21.7 \\
\hline Total & 5205.8 & 2657.1 & 82.9 & -50.7 \\
\hline
\end{tabular}

Source: Author.

At the sector level (Table 6 panel $6 \mathrm{~b}$ ), it is not surprising that the bulk of the increases in employment income due to the liberalization of services trade is within the diverse services sectors. Particularly, the ACP's Finance and Business and Transportation and Communication service sectors hold the largest gains. There is also an increase in equivalent employment income of about 150 million USD in ACP agriculture. This is attributed to the increase in hiring as output expands due to service import being less restricted. But ACP manufacturing stands to lose by about 113 million USD as some of its workers move towards the less distorted service sectors.

It is important to note that the employment income equivalent of the welfare gain shows that unskilled labor reaps most of the benefits. This is consistent with the high proportion of unskilled labor in the ACP labor supply and their high response to changes in production and trade in services.

\subsection{Effects on output, wages and prices}

Panel $7 \mathrm{a}$ in Table 7 shows that the $50 \%$ reduction of the bilateral tariffs in services trade leads to noticeable increases in the skilled labor's wage of between 0.9 to $3.5 \%$ (except in Central Africa where wage slightly declines). Such an increase in the wage of skilled labor is consistent with the tight supply of skilled labor and the increase in services trade and production, because the service sectors are relatively skilled-intensive. The largest increases are in Caribbean and Pacific and the East Africa groups. Similarly, the nominal wage of unskilled labor slightly increases, except for West Africa and Central Africa, but at a slower pace. 
Table 7. Net effects of halving the ACP-EU bilateral services tariffs on production and prices

(7a). Changes in input and output prices (in percentage points)

\begin{tabular}{|c|c|c|c|c|c|c|c|}
\hline & $\begin{array}{c}\text { Eastern and } \\
\text { Southern Africa }\end{array}$ & East Africa & West Africa & Central Africa & SADC & $\begin{array}{l}\text { Caribbean } \\
\text { and Pacific }\end{array}$ & $\mathrm{EU}+\mathrm{UK}$ \\
\hline Land & 0.28 & 0.67 & 0.02 & -1.28 & 0.04 & -0.26 & 0.34 \\
\hline Unskilled Labor & 0.47 & 1.27 & -0.07 & -0.52 & 0.4 & 1.75 & 1.29 \\
\hline Skilled Labor & 1.72 & 3.35 & 0.92 & -0.69 & 1.1 & 3.52 & -1.09 \\
\hline Capital & 1.56 & 2.59 & 0.7 & 0.19 & 0.97 & 3.32 & 0.3 \\
\hline Natural Resources & -2.32 & -4.04 & -1.08 & 1.2 & -2.77 & -9.36 & 1.92 \\
\hline Agri-Food & 0.62 & 1.56 & 0.07 & -0.51 & 0.51 & 1.68 & 0.12 \\
\hline Extraction & 0.07 & 0.15 & 0.03 & 0 & 0.05 & 0.03 & 0.02 \\
\hline Textile \& Wearing App & 0.56 & 1.2 & 0.07 & -0.54 & 0.47 & 1.67 & 0.36 \\
\hline Manufacturing & 0.55 & 1.25 & 0.1 & -0.48 & 0.46 & 1.39 & -0.42 \\
\hline $\begin{array}{l}\text { Transport \& Communication } \\
\text { Serv. }\end{array}$ & 0.61 & 1.64 & 0 & -0.48 & 0.55 & 1.91 & -0.08 \\
\hline Utility Serv. & 0.75 & 1.52 & 0.07 & -0.3 & 0.52 & 1.65 & -0.02 \\
\hline Construction Serv & 0.7 & 1.76 & 0.2 & -0.43 & 0.63 & 2.18 & 0.42 \\
\hline Finance \& BusIness Serv & 0.83 & 1.84 & -0.03 & -0.7 & 0.63 & 2.17 & 0.24 \\
\hline Government Serv. & 1.08 & 1.79 & -0.01 & -0.72 & 0.66 & 2.3 & 0.03 \\
\hline Recreational Serv. & 0.94 & 1.82 & 0.19 & -0.77 & 0.55 & 2.26 & 0.28 \\
\hline
\end{tabular}

Source: Author.

(7b). Change in output volume (in percentage points)

\begin{tabular}{|l|c|c|c|c|c|c|c|}
\hline & $\begin{array}{c}\text { East and Southern } \\
\text { Africa }\end{array}$ & East Africa & West Africa & Central Africa & SADC & $\begin{array}{c}\text { Caribbean } \\
\text { and Pacific }\end{array}$ & EU+UK \\
\hline Agri-Food & -0.30 & -0.69 & -0.06 & -0.58 & -0.40 & -1.51 & 0.03 \\
\hline Extraction & -0.48 & -1.20 & -0.26 & 0.17 & -0.58 & -1.98 & 0.02 \\
\hline Textile \& Wearing App & -2.09 & -3.42 & -0.20 & -0.43 & -0.73 & -5.05 & 0.00 \\
\hline Manufacturing & -0.79 & -3.59 & 0.35 & 1.93 & -1.13 & -4.46 & 0.03 \\
\hline $\begin{array}{l}\text { Transport and Communication } \\
\text { Serv. }\end{array}$ & 3.86 & 6.18 & 3.93 & 1.17 & 2.40 & 4.21 & -0.10 \\
\hline Utility Serv. & -0.06 & -0.85 & 0.26 & -0.03 & -0.44 & -0.98 & 0.00 \\
\hline Construction Dew Serv. & 0.83 & 1.25 & 1.59 & 1.86 & 0.84 & 2.83 & 0.05 \\
\hline Finance and Business Serv. & 0.91 & 0.77 & 0.22 & -0.39 & 0.37 & 1.26 & 0.02 \\
\hline Government Serv. & 0.64 & 1.98 & 0.88 & -1.11 & 0.55 & 0.92 & -0.03 \\
\hline Recreational Serv. & -0.04 & -0.68 & -0.13 & -0.89 & -0.28 & -0.77 & 0.01 \\
\hline
\end{tabular}

Source: Author.

Panel 7a also reports that the liberalization of services trade will trigger slight increases in output prices in almost every sector and for all ACP groups (except Central Africa). For instance, Agriculture in particular experiences a $1.68 \%$ increase in price in the Pacific and Caribbean, but such increase may not affect food security much. The highest price increase is the $2.3 \%$ for the Government services and the Recreation services in the Caribbean and Pacific group; such an increase in output prices may be linked to the importance of tourism industry in these group of countries.

The impacts of the liberalization of services trade on outputs (Table 7b) look more noticeable in comparison to the impacts on prices. It is no surprise that output increases are in key service sectors such as Transportation and Communication sector (e.g. more than 6\% increase in East Africa and 4.2\% in the Caribbean and Pacific) and the Construction sector (almost 3\% in the Caribbean and Pacific). The results for other ACP sectors are mixed. Agricultural outputs decline but only slightly for the African groups (less than $0.7 \%$ ), whereas the decline is $1.51 \%$ for the Caribbean and Pacific (still not huge). Manufacturing outputs in East Africa and in the Caribbean 
and Pacific will shrink by $3.6 \%$ and $4.5 \%$, respectively. Contrastingly, manufacturing outputs for West and Central Africa will slightly rise by $0.35 \%$ and $1.9 \%$, respectively. The changes in volume of outputs in the key sectors are mainly tied to the movement of factors (especially labor and capital) to the service sectors as the latter grow faster and receive higher growth in prices, attracting labor and capital.

\section{Conclusions}

Trade in services between the ACP and the EU+UK is currently highly protected, and its liberalization has been stalled due to uncertainties over the impact on welfare and especially employment. I analyzed the impact on welfare and employment of a halving of the bilateral tariffs in services trade between the EU+UK and ACP countries. Because of the important role of labor inputs in the service sectors and of the huge labor productivity gaps between the ACP and the EU+UK, I included projections of the growth rates of labor productivity for all trading regions in the simulation. In the model I divided the ACP countries into six groups: five African groups and the Caribbean and Pacific group.

The simulation shows that although ACP services export represents only about $24 \%$ of its total exports to and $28 \%$ of its imports from the EU+UK, halving the bilateral tariffs in services trade between the ACP and the EU+UK generates a welfare gain 3.4 times larger than what comes from the elimination of bilateral tariffs on goods alone. Similarly, liberalization of services trade generates significant endowment effects equivalent to 410 thousand new jobs per year, mostly in service sectors. The employment and welfare gains reach key sectors such as agriculture due to reduction in the services trade costs. The liberalization of services trade also increases wages, especially for skilled labor in ACP countries. All these ACP gains will be enhanced if its labor productivity increases. Apart from a slight reduction in wage of skilled labor, the EU+UK's welfare will increase by about 7.8 billion USD.

The major implications of these findings are that the liberalization of the highly distorted services trade between the ACP and the EU+UK should not be delayed. Interestingly, both the EU+UK and ACP blocs can benefit (both in terms of welfare and employment creation) from an EPA with reduced tariff in services trade. To boost their post-pandemic recoveries, while pondering over the implementation of full reciprocal agreement on goods trade, both parties should not be afraid to conclude agreement on the reduction of services tariffs. Even a sensible reduction in trade costs in services will help unlock the trade potential of ACP countries' services and enhance their contribution to the economy, while helping the EU+UK solve their own employment problems..

The simulation reported here is only a first step to uncover the impacts of a partial liberalization of services trade and employs a static model to assess what the immediate effects will be. The next steps shall include investigating the importance of the timing of partial or full tariff reductions on capital stock and investment. A better handling of the estimation of trade costs in services is also needed. Additionally, new research should include contemporary trade contexts such as the effects of Brexit, of the African Continental Free Trade Area, and of other existing or planned bilateral and multilateral agreements that involve either the EU+UK or the ACP blocs. These steps will help increase the applicability and accuracy of projections of the impacts of services trade liberalization on both the ACP and EU+UK's economies.

\section{Acknowledgement}

This research has received no funding from any agency. The author thanks Badri G. Narayanan, and Marino Tsigas for their valuable comments and suggestions. Views expressed in this paper are the author's own and do not represent the official views of any institutions.

Funding: self-funded.

Author contribution: conceptualization, Manitra A. Rakotoarisoa; data curation, Manitra A. Rakotoarisoa; formal analysis, Manitra A. Rakotoarisoa; funding acquisition, Manitra A. Rakotoarisoa; investigation, Manitra A. Rakotoarisoa; methodology, Manitra A. Rakotoarisoa; project administration, Manitra A. Rakotoarisoa; resources, Manitra A. Rakotoarisoa; software, Manitra A. Rakotoarisoa; supervision, Manitra A. Rakotoarisoa; 
validation, Manitra A. Rakotoarisoa; visualization, Manitra A. Rakotoarisoa; writing - original draft, Manitra A. Rakotoarisoa; writing - review \& editing, Manitra A. Rakotoarisoa.

\section{References}

1. Bendini R. Armonivica M. De Goede W. (2012). Economic Partnership Agreements: EU- ACP: Facts and Key Issues. Report by the European Parliament, Office for Promotion of Parliamentary Democracy. [Link].

2. Brenton, P (2010). Africa Trade in Services and the Economic Partnership Negotiations. Trade Negotiation Insights 9 (9). [Link].

3. Cattaneo O., Engman M., Saez S., Stern R. (2010). International Trade in Services. New Trend and Opportunities for Developing Countries. The World Bank. Washington DC. [Link].

4. Fontagné L., Guillin A., Mitaritonna,C. (2011). Estimations of Tariff Equivalents for the Service Sectors. CEPII Working Paper 2011-24. [Link].

5. Global Trade Analysis Project (GTAP) Database 8. Various years. Purdue University. [Link].

6. Hertel T. (1997). Global Trade Analysis: Modelling and Applications, Cambridge University Press. [Link].

7. Narayanan, B., Walmsley T. (2008). Global Trade, Assistance, and Production: The GTAP 7 Data Base, Center for Global Trade Analysis, Purdue University. [Link].

8. Van Dijk, M., (2013). Productivity Growth at the Sectoral Level: Measurement and Projections. Selected Paper for the 16th Annual Conference on Global Economic Analysis. GTAP Conference Paper, no. 4106. [Link].

9. Van Leeuwen, N., Lejour A.(2005). Bilateral Services Trade Data and the GTAP DataBase. Selected Paper for the 8th Annual Conference on Global Economic Analysis GTAP, Conference Paper no.1826. [Link].

10. Van Limburg, L (2010). Cross-Border Trade in Services: Barriers and Opportunities in the EU Services Markets for ACP Exporters. Trade Negotiation Insights, 9 (9). [Link].

11. World Trade Organization (2012). The Trade Effects of Non-Tariff Measures and Services Measures. In World Trade Report. Chap D. page 134. [Link].

\section{Annex 1: The sectors}

1. Raw Food and Agriculture: Paddy rice; Wheat; Cereal grains nec; Vegetables, fruit, nuts; Oil seeds; Sugar cane, sugar beet; Plant-based fibers; Crops nec; Cattle, sheep, goats, horses; Animal products nec; Raw milk; Wool, silk-worm cocoons; Meat: cattle, sheep, goats, horse; Meat products nec.

2. Processed Food: Vegetable oils and fats; Dairy products; Sugar; Food products nec; Beverages and tobacco products; Processed rice.

3. Extraction (Mining and Extraction): Forestry; Fishing; Coal; Oil; Gas; Minerals nec.

4. TextWapp (Textile and Apparel): Textiles; Apparel.

5. LightMnfc (Light Manufacturing): Leather products; Wood products; Paper products, publishing; Metal products; Motor vehicles and parts; Transport equipment nec; Manufactures nec.

6. HeavyMnfc (Heavy Manufacturing): Petroleum, coal products; Chemical,rubber, plastic prods; Mineral products nec; Ferrous metals; Metals nec; Electronicequipment; Machinery and equipment nec.

7. Services: Electricity; Gas manufacture, distribution; Water; Construction; Trade; Transport nec; Sea transport; Air transport; Communication; Financial services nec; Insurance; Business services nec; Recreation and other services; Public Administration/Defence/Health/Education; Dwellings.

\section{Annex 2: The EPA regions}

West Africa: Benin, Burkina Faso, Cape Verde, Ivory Coast, Gambia, Ghana, Guinea, Guinea-Bissau, Liberia, Mali, Niger, Nigeria, Senegal, Sierra Leone, Togo, Mauritania.

Central Africa: Cameroon, Central African Republic, Chad, Congo (Brazzaville), Congo Democratic Republic of (Kinshasa), Equatorial Guinea, Gabon, São Tomé \& Principe.

Eastern and Southern Africa: Comoros, Djibouti, Eritrea, Ethiopia, Madagascar, Malawi, Mauritius, Seychelles, Sudan, Zambia, Zimbabwe. 
East Africa: Kenya, Uganda, Tanzania, Burundi and Rwanda.

Southern African Development Community: Angola, Botswana, Lesotho, Mozambique, Namibia, South Africa, Swaziland.

Caribbean: Antigua and Barbuda, Bahamas, Barbados, Belize, Dominica, Dominican Republic, Grenada, Guyana, Haiti, Jamaica, St Lucia, St Vincent and the Grenadines, St Kitts and Nevis, Suriname, Trinidad and Tobago.

Pacific $^{3}$ : Cook Islands, Fiji, Kiribati, Marshall Islands, Micronesia, Federated States of, Nauru, Niue, Palau, Papua New Guinea, Samoa American, Samoa Western, Solomon Islands, Tonga, Tuvalu, Vanuatu. Along these seven regions, the model also include the following regions: The Middle-East and North Africa (MENA); North America; Southern and Central America; EU+UK; Brazil, Russia, India and China (BRIC); Asia Developing (incl. Vietnam, Malaysia); Japan and the Asian Tigers; Oceania (Australia and New Zealand); and the Rest of the World.

\footnotetext{
${ }^{3}$ In the analysis, the Caribbean and the Pacific countries are often merged into the Caribbean and Pacific group.
} 